\title{
Marktverkenning European law school
}

Citation for published version (APA):

Kruisinga, A., Ramaekers, G. W. M., \& van der Velden, R. K. W. (1993). Marktverkenning European law school. Researchcentrum voor Onderwijs en Arbeidsmarkt, Faculteit der Economische Wetenschappen. ROA Reports No. 11 https://doi.org/10.26481/umarep.1993011

Document status and date:

Published: 01/01/1993

DOI:

10.26481/umarep.1993011

Document Version:

Publisher's PDF, also known as Version of record

\section{Please check the document version of this publication:}

- A submitted manuscript is the version of the article upon submission and before peer-review. There can be important differences between the submitted version and the official published version of record.

People interested in the research are advised to contact the author for the final version of the publication, or visit the DOI to the publisher's website.

- The final author version and the galley proof are versions of the publication after peer review.

- The final published version features the final layout of the paper including the volume, issue and page numbers.

Link to publication

\footnotetext{
General rights rights.

- You may freely distribute the URL identifying the publication in the public portal. please follow below link for the End User Agreement:

www.umlib.nl/taverne-license

Take down policy

If you believe that this document breaches copyright please contact us at:

repository@maastrichtuniversity.nl

providing details and we will investigate your claim.
}

Copyright and moral rights for the publications made accessible in the public portal are retained by the authors and/or other copyright owners and it is a condition of accessing publications that users recognise and abide by the legal requirements associated with these

- Users may download and print one copy of any publication from the public portal for the purpose of private study or research.

- You may not further distribute the material or use it for any profit-making activity or commercial gain

If the publication is distributed under the terms of Article $25 \mathrm{fa}$ of the Dutch Copyright Act, indicated by the "Taverne" license above, 
MARKTVERKENNING EUROPEAN LAW SCHOOL

ROA-R-1993/11
A. Kruisinga
G.W.M. Ramaekers
R.K.W. van der Velden

RESEARCHCENTRUM VOOR ONDERWIJS EN ARBEIDSMARKT

Faculteit der Economische Wetenschappen

Rijksuniversiteit Limburg

Maastricht, november 1993 


\section{CIP-GEGEVENS KONINKLIJKE BIBLIOTHEEK, DEN HAAG}

Kruisinga, $A$.

Marktverkenning European Law School / A. Kruisinga, G.W.M. Ramaekers, R.K.W. van der Velden. - Maastricht : Researchcentrum voor Onderwijs en Arbeidsmarkt, Faculteit der Economische Wetenschappen, Rijksuniversiteit Limburg. - ([Rapport / Researchcentrum voor Onderwijs en Arbeidsmarkt, ISSN 0922-8098; ROA-R-1993/11)

Met lit. opg.

ISBN 90-5321-114-4

Trefw.: arbeidsmarkt ; juristen ; onderzoek. 


\section{INHOUDSOPGAVE}

Bladzijde

1. INLEIDING

2. OPZET VAN HET ONDERZOEK 2

3. ARBEIDSMARKTPOSITIE VAN JURISTEN 4

3.1. Arbeidsmarktpositie van Limburgse juristen 4

3.2. Algemene indicatoren met betrekking tot de arbeidsmarkt voor juristen 5

3.3. Verwachte ontwikkelingen in het werkveld $\quad 8$

4. DE ARBEIDSMARKTPERSPECTIEVEN VOOR EN TE STELLEN EISEN AAN AFGESTUDEERDEN VAN DE ELS 10

4.1. De werkgelegenheid voor Europeesrechtelijke juristen 10

4.1.1. De huidige arbeidsmarkt voor juristen in het algemeen 10

4.1.2. De huidige arbeidsmarkt voor Europeesrechtelijke juristen 10

4.1.3. De toekomstige behoefte aan Europeesrechtelijke juristen 12

4.1.4. De concurrenten van de ELS $\quad 13$

4.2. De eisen voor Europeesrechtelijke juristen 13

4.2.1. Kennis van het Nederlands recht 13

4.2.2. Houdingen en vaardigheden 14

4.2.3. Talenkennis 14

4.2.4. Ervaring in het buitenland 15

4.3. De European Law School 15

4.3.1. Het concept van de European Law School 15

4.3.2. Het civiel effect van de opleiding 15

4.3.3. De verhouding nationaal-Europeesrechtelijk curriculum 16

4.3.4. Een pre- of postdoctorale opleiding? 17

$\begin{array}{ll}\text { 4.3.5. De buitenlandse studenten } & 17\end{array}$

4.3.6. De selectiviteit van de opleiding 17

4.3.7. Accent op Europees recht of op rechtsvergelijking? $\quad 18$

4.3.8. De wenselijkheid van een specialisatie naar land 19

4.3.9. De wenselijkheid van een specialisatie naar rechtsgebied 19

4.3.10. Een buitenlandse stage of studie 19

4.3.11. De buitenlandse talen 20

5. SAMENVATTING EN CONCLUSIES 21

5.1. De werkgelegenheid voor Europeesrechtelijke juristen $\quad 21$

5.2. De eisen voor Europeesrechtelijke juristen $\quad 21$

$\begin{array}{ll}\text { 5.3. De European Law School } & 21\end{array}$

$\begin{array}{lr}\text { 6. AANBEVELINGEN } & 23\end{array}$

$\begin{array}{lr}\text { LITERATUUR } & 26\end{array}$

BIJLAGE 1. LIJST VAN GEINTERVIEWDE PERSONEN 27

BIJLAGE 2. CONCURRERENDE OPLEIDINGEN 29 


\section{INLEIDING}

De Commissie Internationalisering van de Faculteit der Rechtsgeleerdheid (FdR) van de Rijksuniversiteit Limburg heeft in het najaar van 1992 een nota geschreven waarin de mogelijkheden worden verkend om te komen tot een European Law School (ELS) ${ }^{1}$. Hoofddoel van deze nieuwe opleiding is om studenten op te leiden tot Europese juristen, in zekere zin vergelijkbaar met de Amerikaanse Law School die ook een staatsoverschrijdend karakter heeft.

Het Researchcentrum voor Onderwijs en Arbeidsmarkt (ROA) is gevraagd om een onderzoek uit te voeren naar de arbeidsmarktperspectieven van deze nieuwe opleiding. Het onderzoek is uitgevoerd door een projectteam bestaande uit drs. G.W.M. Ramaekers en dr. R.K.W. van der Velden (projectleider), beiden vanuit het ROA, en A. Kruisinga, die als student-assistent vanuit de FdR ten behoeve van het project bij het ROA is gedetacheerd.

Het voorliggende onderzoeksverslag is als volgt opgebouwd. In hoofdstuk 2 wordt de opzet van het onderzoek geschetst. Hoofdstuk 3 geeft een algemene beschrijving van de arbeidsmarktpositie van juristen. In hoofdstuk 4 worden de belangrijkste resultaten van het onderzoek geschetst. Hoofdstuk 5 bevat de conclusies en hoofdstuk 6 de aanbevelingen. In de bijlagen is een lijst opgenomen met geïnterviewde personen, alsmede een overzicht van concurrerende opleidingen op de arbeidsmarkt.

1. Commissie Internationalisering (1992). 


\section{OPZET VAN HET ONDERZOEK}

Het onderzoek heeft een tweeledig doel. In de eerste plaats een verkenning van de arbeidsmarktmogelijkheden voor afgestudeerden van de ELS. In de tweede plaats een verkenning van de eisen die het afnemende veld aan de afgestudeerden stelt, en de consequenties daarvan voor de opbouw en inhoud van het curriculum.

Met betrekking tot het onderzoek naar de arbeidsmarktmogelijkheden zijn de volgende vragen geformuleerd.

* In welke organisaties kunnen afgestudeerden van de ELS werkzaam zijn?

* Zijn er specifieke functies voor afgestudeerden van de ELS?

* Bestaan deze functies reeds of moeten deze nog gecreëerd worden?

* Door wie worden deze functies nu vervuld, met andere woorden welke aanbodscategorieën zijn de concurrenten voor afgestudeerden van de ELS?

* Zijn er indicaties dat voor dit type functies onvoldoende (geschikt) aanbod bestaat op de arbeidsmarkt?

Naast deze verkenning van de arbeidsmarktmogelijkheden is nagegaan in welk opzicht afgestudeerden van de ELS zich zouden moeten onderscheiden om concurrerend te kunnen opereren op de arbeidsmarkt en op welke aspecten in de opleiding het accent moet komen te liggen. Hierbij zijn de volgende thema's onderscheiden.

In de eerste plaats is nagegaan in hoeverre de opleiding een civiel effect moet hebben voor de (Nederlandse) advocatuur en rechterlijke macht. In aansluiting op deze vraag is ook nagegaan hoe de opbouw van het curriculum er in hoofdlijnen zou moeten uitzien.

In de tweede plaats is nagegaan of men in de opleiding een specialisering wenselijk acht of dat de opleiding juist breed moet worden ingericht. Bij specialisering kan men zowel denken aan een specialisering naar land (bijvoorbeeld de combinatie Nederlands en Frans recht) of naar rechtsgebied, bijvoorbeeld kennis op het gebied van (Europese) mediawetgeving of arbeidsrecht.

In de derde plaats is geïnventariseerd of in de opleiding het accent moet liggen op de Europese wet- en regelgeving of juist op de rechtsvergelijking tussen landen.

Gelet op de vraagstelling heeft het onderzoek voornamelijk een verkennend karakter. In dit kader zijn 27 gesprekken gevoerd met potentiẻle afnemers van de ELS en met andere betrokken organisaties. In deze interviews hebben bovengenoemde vragen en thema's gefungeerd als leidraad bij de gesprekken. In bijlage 1 is een lijst van geïnterviewde personen en organisaties opgenomen.

Deels hebben gesprekken plaatsgevonden met sleutelfiguren die op grond van hun specifieke functie of deskundigheid een meer algemeen oordeel konden geven over de arbeidsmarktperspectieven voor en te stellen eisen aan afgestudeerden van de ELS. Daarnaast hebben 
gesprekken plaatsgevonden met organisaties waar afgestudeerden van de ELS mogelijk werkzaam zouden kunnnen zijn, zoals ministeries, grote bedrijven, grote advocatenkantoren en Europese instellingen. Bij deze potentiële afnemers is meestal gesproken met degene die verantwoordelijk is voor de werving en selectie voor de juridische functies.

De gesprekken zijn steeds gevoerd door 2 interviewers. Alle gesprekken zijn opgenomen op band. Een samenvattend verslag van elk gesprek is aan de gesprekspartners voorgelegd met het verzoek om eventuele correcties aan te brengen of aanvullingen te geven.

In het algemeen was er een grote bereidheid om aan het onderzoek mee te werken. Slechts in een enkel geval weigerde men medewerking, meestal omdat men van mening was dat men geen zinvolle bijdrage aan het gespreksonderwerp zou kunnen leveren. De hoge respons heeft waarschijnlijk deels te maken met het feit dat men het onderwerp interessant vond. Anderzijds werd het door de gesprekspartners op prijs gesteld dat men kon 'meedenken' over de opzet van een nieuwe opleiding. Immers, meestal worden nieuwe opleidingen gestart zonder voorafgaand marktonderzoek. In die zin heeft het onderzoek ook een duidelijke P.R.-functie gehad. 


\section{ARBEIDSMARKTPOSITIE VAN JURISTEN}

\subsection{Arbeidsmarktpositie van Limburgse juristen ${ }^{2}$}

In een onderzoek onder 343 juristen die in de periode 1986-1989 aan de RL afstudeerden, is naar voren gekomen dat hun intrede op de arbeidsmarkt vrij moeizaam verloopt. Drie maanden na afstuderen heeft $39 \%$ een betaalde baan gevonden. $\mathrm{Na}$ zes maanden bedraagt het percentage 48 , om daarna te stijgen tot $60 \%$ één jaar na verlaten van de RL. Op het moment van enquêteren heeft $71 \%$ betaald werk gevonden, terwijl $13 \%$ werkloos is. Ruim een kwart (27\%) van de betaald werkende juristen heeft een vaste baan gevonden. Gebleken is dat juristen hun eerste baan relatief zelden via open sollicitaties verwerven, zoals medici en economen, maar vaak door, evenals gezondheidswetenschappers, op vacature-advertenties te solliciteren.

Voor een baan zijn juristen in vrijwel gelijke mate aangewezen op de niet-zakelijke dienstverlening $(48 \%)$ - met name openbaar bestuur en onderwijs - als op de bedrijfstak 'banken verzekeringswezen, zakelijke dienstverlening' (42\%), met name rechtskundige diensten. De helft van de betaald werkende juristen $(51 \%)$ werkt in grote organisaties met meer dan 99 werknemers. Eenvijfde werkt in kleine organisaties met minder dan 10 personeelsleden, waaronder met name advocatenkantoren. De meerderheid $(70 \%)$ van de betaald werkenden komt terecht op de Limburgse arbeidsmarkt.

Meer dan de helft $(59 \%)$ van de betaald werkende juristen oefent het beroep van jurist uit. De rest komt vooral in administratieve functies terecht. lets meer dan eenderde (35\%) geeft te kennen dat voor hun functie wel een juridische opleiding maar geen specifieke specialisatie is vereist. Ondanks de bevinding dat zij al over vrij veel beroepen binnen het 'eigen' beroependomein zijn verspreid, is de werkloosheid onder de onderzochte juristen relatief hoog. Mogelijk slagen zij er in onvoldoende mate in om buiten het 'eigen' beroependomein werk te vinden. De meerderheid $(73 \%)$ werkt dan ook in functies waarvoor een rechtenopleiding specifiek is vereist.

Met betrekking tot het niveau van de functie komt naar voren dat $79 \%$ van de betaald werkende juristen een functie uitoefent waarvoor een academische opleiding is vereist, $27 \%$ een leidinggevende functie uitoefent en $37 \%$ een bruto maandinkomen verwerft dat ligt binnen de voor de onderzochte juristen modale inkomensklasse van Fl. 3.000 - Fl. 3.750 bij een volledige werkweek.

2. Ramaekers, Heijke (1991), blz. 100-101. 


\subsection{Algemene indicatoren met betrekking tot de arbeidsmarkt voor juristen}

In deze paragraaf wordt eerst arbeidsmarktinformatie met betrekking tot de beroepsklasse 'advocaten, officieren van justitie, rechters en notarissen' gepresenteerd, gevolgd door arbeidsmarktinformatie over het opleidingstype 'WO Rechten \& Bestuurskunde' ${ }^{3}$. Vervolgens wordt de ontwikkeling van het aantal afgestudeerde juristen tot het jaar 2005 geschetst.

In tabel 3.1. wordt een aantal indicatoren met betrekking tot de arbeidsmarktpositie van de beroepsklasse 'advocaten, officieren van justitie, rechters en notarissen' gepresenteerd. De conjunctuurindicator geeft aan in welke mate de werkgelegenheid gevoelig is voor conjuncturele ontwikkelingen, gemeten over een lange periode. De spreidingsindicator geeft de mate aan waarin werkenden kunnen uitwijken naar een andere bedrijfssector. De baanopeningen zijn opgebouwd uit de uitbreidingsvraag, ofwel de werkgelegenheidsontwikkeling, en de vervangingsvraag, d.w.z. de baanopeningen die ontstaan als gevolg van pensionering e.d.

Tabel 3.1. Arbeidsmarktindicatoren met betrekking tot de beroepsklasse 'advocaten, officieren van justitie, rechters en notarissen', 1989-1994

conjunctuurgevoeligheid

sectorspreiding in 1988-1991

uitbreidingsvraag $(73 \%)$

vervangingsvraag $(27 \%)$

baanopeningen

$\begin{array}{ll}1.23 & \text { klein } \\ 0.71 & \begin{array}{l}\text { gemiddeld; trend: } \\ \text { constant }\end{array} \\ 6.500=21 \% & \text { hoog } \\ 2.500=8 \% & \text { laag } \\ 8.900=29 \% & \text { hoog }\end{array}$

In tabel 3.1 komt naar voren dat voor de zeer nabije toekomst de vraag naar nieuwkomers in deze beroepsklasse verhoudingsgewijs hoog is, vooral als gevolg van een uitbreiding van de werkgelegenheid. De conjunctuurgevoeligheid van de werkgelegenheid is klein en de uitwijkmogelijkheden naar andere bedrijfssectoren zijn gemiddeld ${ }^{4}$.

In tabel 3.2. wordt een aantal indicatoren met betrekking tot de arbeidsmarktpositie van het opleidingstype 'WO Rechten \& Bestuurskunde' gepresenteerd. In deze tabel worden zowel de uitwijkmogelijkheden naar andere bedrijfssectoren als de vitwijkmogelijkheden naar andere beroepsklassen weergegeven. Daarnaast wordt het werkloosheidspercentage, de werkloosheid onder schoolverlaters en de mate van onderbenutting in beeld gebracht. De

3. De hier gepresenteerde gegevens zijn ontleend aan het Informatiesysteem Onderwijs-Arbeidsmarkt dat het ROA in opdracht van het ministerie van Onderwijs en Wetenschappen ontwikkeld heeft. Dit systeem bevat informatie over 93 beroepsklassen en 49 opleidingstypen. Vanwege de aantallen zijn bepaalde opleidingen soms samengevoegd tot eén opleidingstype, zoals hier de studierichtingen Recht en Bestuurskunde.

4. Researchcentrum voor Onderwijs en Arbeidsmarkt (1992), blz. 47 
werkloosheidsgegevens schetsen, samen met het percentage werkenden dat een baan heeft beneden het eigen opleidingsniveau (onderbenutting), een beeld van de actuele arbeidsmarktsituatie. Het werkloosheidspercentage geeft daarbij een indicatie van het bestaan van kwantitatieve aansluitingsproblemen tussen de vraag naar en het aanbod van het betreffende opleidingstype, terwijl de mate van onderbenutting informatie geeft over kwalitatieve aansluitingsproblemen. In de typering van de verwachte toekomstige arbeidsmarktsituatie staat de confrontatie van de verwachte ontwikkeling aan de aanbod- en de vraagzijde van de arbeidsmarkt centraal. De aanbodontwikkeling is opgebouwd uit het aantal kortdurig werklozen aan het begin van de prognoseperiode en de verwachte instroom van schoolverlaters op de arbeidsmarkt. De vraagzijde betreft de ontwikkeling van het aantal baanopeningen gedurende de prognoseperiode, en bestaat uit de uitbreidings- en de vervangingsvraag.

Tabel 3.2. Arbeidsmarktindicatoren met betrekking tot het opleidingstype 'WO Rechten \& Bestuurskunde', 1989-1994

Indicator

werkloosheid schoolverlaters *

werkloosheid beroepsbevolking*

onderbenutting in 1990-1991

beroepsgroepenspreiding in 1990-1991

sectorspreiding in 1990-1991

vervangingsvraag

uitbreidingsvraag

baanopeningen

instroom schoolverlaters

toekomstige arbeidsmarktsituatie
Omvang

$7 \%$

$4 \%$

$17 \%$

0.82

0.82

$3.700=8 \%$

$8.200=17 \%$

$11.800=25 \%$

$24.700=53 \%$

1.25
Typering

gemiddeld

gemiddeld; trend:

dalend

laag

gemiddeld; trend:

constant

gemiddeld; trend:

constant

gemiddeld

gemiddeld

gemiddeld

erg hoog

slecht

* in aprii 1991

In tabel 3.2 komt naar voren dat de werkloosheid voor dit opleidingstype momenteel ongeveer gelijk is aan het gemiddelde over alle opleidingstypen. Voor de zeer nabije toekomst zijn de arbeidsmarktperspectieven echter slecht: tegenover een gemiddleld aantal baanopeningen staat, tenminste op de zeer korte termijn, een erg hoge instroom van afgestudeerden ${ }^{6}$.

In tabel 3.2. is naar voren gekomen dat de huidige en op zeer korte termijn te verwachten arbeidsmarktsituatie van afgestudeerde juristen in hoge mate wordt bepaald door het aantal afgestudeerden. Grafiek 3.1 geeft een beeld van de ontwikkeling van het aantal afgestudeerden op (middel-)lange termijn.

5. Researchcentrum voor Onderwijs en Arbeidsmarkt (1992), blz. 86. 


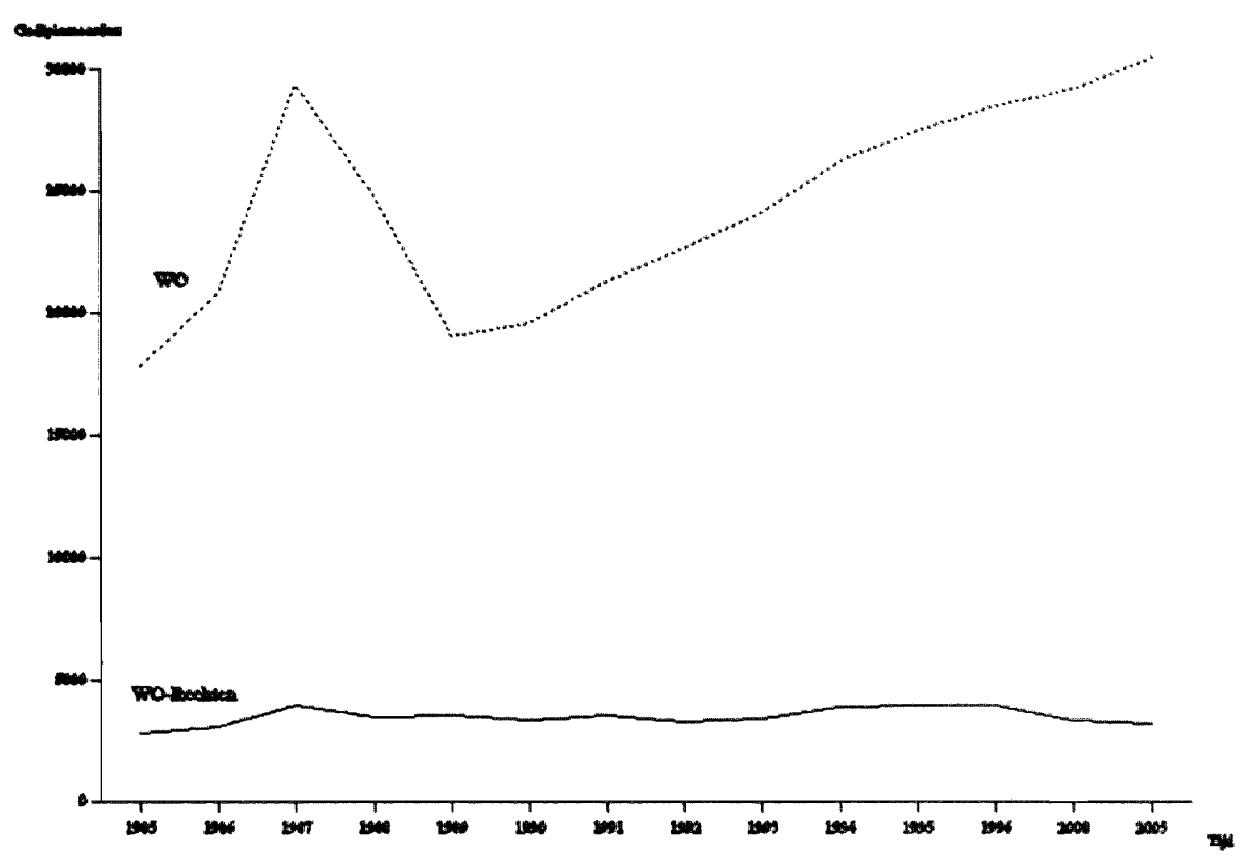

Bron: Ministerie van Onderwijs en Wetenschappen, 1993

In grafiek 3.1 komt naar voren dat de totale uitstroom uit het WO in 1987 een duidelijke piek vertoont. De reden hiervoor is het gelijktijdig afstuderen van de laatste generatie 'oude fase' studenten en de eerste generatie tweede fase studenten. Vanaf 1989 neemt de totale uitstroom uit het WO sterk toe: van 19.614 in 1990 , via 27.476 in 1995 en 29.197 in 2000, tot 30.467 in 2005. Het aantal juristen dat jaarlijks afstudeert neemt in de eerste helft van de jaren negentig eveneens toe, van 3.357 in 1990 tot 3.991 in 1995. Daarna wordt echter een daling verwacht van het aantal juristen dat jaarlijks afstudeert, namelijk via 3.386 in het jaar 2000 tot 3.192 in 2005. Dit betekent dat de arbeidsmarktpositie voor intredende juristen na 1995 zal verbeteren, tenminste uit het oogpunt van de daling van het aantal instromende juristen. Daarbij komt dat juridisch opgeleiden redelijk flexibel op de arbeidsmarkt kunnen opereren, gezien hun 'gemiddelde' uitwijkmogelijkheden naar andere beroepen en bedrijfssectoren. Daar staat echter tegenover dat juristen die uitwijken naar andere, niet-specifiek juridische functies en bedrijfssectoren in toenemende mate zullen worden geconfronteerd met groeiende aantallen academici die in andere disciplines zijn afgestudeerd. In het eerder genoemde ROA-onderzoek onder juristen die aan de RL zijn afgestudeerd, is naar voren gekomen dat circa een kwart $(27 \%)$ van de betaald werkende juristen functies uitoefenen waarvoor een juridische opleiding niet specifiek is vereist. 


\subsection{Verwachte ontwikkelingen in het werkveld}

In 1988 heeft de Stichting Centrum voor Onderwijsonderzoek (SCO) een onderzoek verricht naar de verwachte ontwikkelingen op de arbeidsmarkt voor juristen en de gevolgen daarvan voor de juridische opleiding ${ }^{6}$. Door middel van een enquête onder deskundigen uit de wetenschappelijke en de arbeidsmarktomgeving van de Faculteit der Rechtsgeleerdheid van de Universiteit van Amsterdam is in het SCO-onderzoek getracht een aantal maatschappelijke ontwikkelingen te identificeren die hun weerslag zullen hebben op de vraag naar juristen in de komende tien jaren (basisjaar 1988). Naast verwachtingen van representatieve deskundigen uit de juridische onderwijs- en arbeidsvelden, zijn de prognoses gebaseerd op externe studies, namelijk het Hoger Onderwijs- en Onderzoekplan van het Ministerie van Onderwijs en Wetenschappen en het werkdocument De arbeidsmarkt naar opleidingscategorie 1975-2000 van het Centraal Planbureau.

Met name de toenemende juridificering en internationalisering van de samenleving zullen naar de mening van de door de SCO bevraagde deskundigen leiden tot een toename van de werkgelegenheid voor juristen in de zakelijke dienstverlening ladvocaten, belastingadviseurs, juridisch adviseurs, bedrijfsjuristen en directiesecretarissen), alsmede voor specifiek juridische functies in de niet-zakelijke dienstverlening (belastingambtenaren, leden van de rechterlijke macht en bestuurs- en wetgevingsjuristen).

In lijnfuncties bij banken en verzekeringen en in commerciële functies in de industrie zullen juristen naar verwachting terrein verliezen, aangezien zij over te weinig bedrijfseconomische en financieel economische kennis beschikken. In niet specifiek juridische ambtelijke functies zullen zij naar verwachting terrein verliezen door de concurrentie van andere academici. Verdringing van lager opgeleiden kan hier wellicht enig soulaas bieden. In het onderwijs en de wetenschap wordt volgens het SCO-onderzoek een afname van de werkgelegenheid voor juristen verwacht, als gevolg van verder gaande bezuinigingen van de overheid en als gevolg van de verwachte terugloop van de aantallen leerlingen. Daarentegen bieden overige niet-zakelijke dienstverlenende instellingen, bijvoorbeeld in de gezondheidszorg, relatief sterke groeimogelijkheden.

Uit een enquête onder ruim 300 werkgevers naar de arbeidsmarktpositie van pas afgestudeerde juristen, verricht door de Faculteit der Rechtsgeleerdheid van de Erasmus Universiteit Rotterdam?, kwam naar voren dat een studie rechten 'goede perspectieven op werk' biedt. De meeste gesprekspartners verwachten een verdergaande lichte groei van de werkgelegenheid voor pas afgestudeerde juristen in specifiek juridische beroepen, zoals bestuurs- en wetgevingsjuristen en leden van de rechterlijke macht. De geinterviewde werkgevers verwachten voorts dat met name voor milieu-juristen, fiscaal-juristen en internationaalrechtelijke juristen het aantal banen zal toenemen.

\footnotetext{
6. Van den Berg Saparoea (1988).

7. Verhulst-van der Lans, Lagrouw (1992).
} 
Gebleken is dat $15 \%$ van de werkgevers het belangrijk vindt dat de aan te trekken jurist in internationaal recht is afgestudeerd. In het Rotterdamse onderzoek is verder naar voren gekomen dat $51 \%$ van de werkgevers een groeiend aantal banen verwacht voor internationaalrechtelijke juristen. Tabel 3.3 geeft hiervan, verdeeld naar bedrijfssector, een beeld. Overigens komt in het onderzoek ook naar voren dat $94 \%$ van de geënquêteerde werkgevers het belangrijk vindt dat in de juridische opleiding, ongeacht de afstudeerrichting, meer aandacht wordt geschonken aan de internationale en Europese dimensie.

Tabel 3.3. Belang van de afstudeerrichting internationaal recht bij de selectie van juristen en toenemende vraag naar internationaalrechtelijke juristen, naar bedrijfssector (in\%)

Belang bij selectie"

Toenemende vraag

verwacht $^{21}$

$\begin{array}{lcc}\text { juridische sector } & 14 \% & 69 \% \\ \text { bedrijfsleven } & 23 \% & 46 \% \\ \text { dienstensector } & 12 \% & 43 \% \\ \text { overheid } & 10 \% & 29 \% \\ \text { totaal } & 15 \% & 51 \% \\ \text { 1) Procentueel aandeel van werkgevers die bij de selectie van pas afgestudeerde juristen het van belang } \\ \text { achten dat de sollicitant in internationaal recht is afgestudeerd. } \\ \text { 2) Procentueel aandeel van werkgevers die verwachten dat het aantal banen voor internationaalrechtelijke } \\ \text { juristen in de komende vijf jaar zal toenemen. }\end{array}$

Bron: Verhulst-van der Lans, Lagrouw (1992), blz. 30, 37.

Met betrekking tot niet specifiek juridische functies wordt ook in het Rotterdamse onderzoek gewezen op de mogelijkheden die verdringing van lager opgeleiden biedt en op het gevaar van concurrentie door andere academici.

Zowel in het eerder besproken SCO-onderzoek als in het bovenbeschreven onderzoek van de Faculteit der Rechtsgeleerdheid van de Erasmus Universiteit Rotterdam kan worden geconcludeerd dat juristen in toenemende mate zullen worden geconfronteerd met het voortschrijdende proces van internationalisering, tot uiting komend in een sterk toegenomen aandacht voor de internationale aspecten van het recht. Een gelijkluidende tendens kon worden gesignaleerd tijdens een symposium dat door de Faculteit der Rechtsgeleerdheid Katholieke Universiteit Nijmegen in 1991 is georganiseerd ${ }^{\natural}$. Een tweede ontwikkeling die door diverse sprekers op dit symposium naar voren werd gebracht betreft een herwaardering van de meer algemeen gevormde jurist. Wat de herwaardering van de juridische generalist betreft werd in dit verband gewezen op de constatering dat vele beroepsgroepen hun eigen praktijkopleidingen zijn gaan organiseren. Dit zou dan voor de juridische faculteiten de mogelijkheid bieden om de aandacht te verschuiven naar algemene en meer theoretische vorming, aldus een opponent (Hassel etal, 1992, blz. 65).

8. Hassel, etal (1992). 


\section{DE ARBEIDSMARKTPERSPECTIEVEN VOOR EN TE STELLEN EISEN AAN AFGESTUDEERDEN VAN DE ELS}

\subsection{De werkgelegenheid voor Europeesrechtelijke juristen}

\subsubsection{De huidige arbeidsmarkt voor juristen in het algemeen}

Zoals in het voorgaande hoofdstuk reeds is aangegeven, is de huidige arbeidsmarkt voor juristen zeer ruim. Slechts enkele van de ondervraagde gesprekspartners zeggen moeite te hebben om geschikte kandidaten te vinden voor de juridische functies binnen hun organisatie. Men verkeert in de luxe positie waarin men de beste kandidaten van de arbeidsmarkt kan afromen en meer eisen kan stellen dan strikt genomen voor de functie noodzakelijk zouden zijn.

Deze ruime arbeidsmarktsituatie leidt er ook toe dat het arbeidsaanbod zich steeds verder kwalificeert om in de race te blijven voor de schaarse aantrekkelijke juridische functies. Met alleen maar een juridische opleiding komt men er niet, en velen proberen zich van hun medestudenten te onderscheiden door een stage te volgen, een tijd in het buitenland te studeren of op een andere wijze een opvallend C.V. bij elkaar te sprokkeien.

Dit algemene beeld over de arbeidsmarktsituatie ligt overigens anders bij hogere functies, bij specialistische functies en bij functies waarbij meer werkervaring is vereist. Bij een adequate opvulling van dergelijke vacatures ervaart men in het algemeen wel problemen.

\subsubsection{De huidige arbeidsmarkt voor Europeesrechtelijke juristen}

Er is een (beperkte) behoefte op de arbeidsmarkt aan juristen die Europeesrechtelijk geschoold zijn of - in meer brede zin - internationaal georiënteerd zijn. Zoals bij alle juridische functies het geval is, geldt dat een grondige kennis van het nationale recht als voorwaarde wordt beschouwd (zie paragraaf 4.2 ).

Bij de overheid bestaat een zekere behoefte aan Europeesrechtelijke juristen. In totaal komen bij de Rijksoverheid jaarlijks circa 1.000 vacatures beschikbaar voor academici. Zo'n 100 tot 150 van deze vacatures zijn specifiek bedoeld voor juristen, waarvan een kwart bestemd is voor de rechterlijke macht en de rest voor de ministeries. Daarnaast stromen nog zo'n 100 tot 150 juristen in op niet-specifiek juridische functies.

- Bij de rechterlijke macht speelt de afstudeerrichting van de juristen geen rol. De Europeesrechtelijk juristen moeten voor de rechterlijke macht in ieder geval aan de toelatingseisen van art. 48 en $59 \mathrm{~b}$ RO voldaan hebben.

- Bij de ministeries bestaat wel een (relatief kleine) markt voor Europeesrechtelijke juristen, althans indien deze ook een gedegen kennis hebben van het nationale recht. Van de meeste juristen die bij de ministeries werken wordt verwacht dat zij een basiskennis hebben van het Europees recht. 
Bij de Europese instellingen is niet direct sprake van een behoefte aan specifiek Europeesrechtelijk geschoolde juristen. De selectie en werving van personeel geschiedt via het zogeheten landenexamen, waarbij niet voor een specifieke functie geworven wordt, maar kandidaten op hun algemene geschiktheid voor een functie bij de EG worden getoetst. Hoewel er afzonderlijke examens bestaan voor juridische functies, is de tendens dat de specifieke opleiding steeds minder belangrijk wordt geacht voor de diverse functies. Het examen staat tegenwoordig dan ook open voor kandidaten die weliswaar geen rechten hebben gestudeerd, maar wel een juridische achtergrond hebben. Na het landenexamen worden de kandidaten op een zogenaamde reservelijst geplaatst, waaruit de keuzes voor de specifieke functies worden gemaakt. Bij deze keuzes speelt de opleiding wel een rol en zouden afgestudeerden van de ELS een voordeel kunnen hebben ten opzichte van 'gewone' juristen.

Bij industriële ondernemingen is de behoefte aan Europeesrechtelijke juristen vrijwel afwezig. Bedrijven geven de voorkeur aan breed opgeleide (bedrijfs)juristen met een grondige kennis van het ondernemings-, vennootschaps-, verbintenissen- en intellectuele eigendomsrecht, die in staat zijn om te beoordelen voor welke zaken men een advocatenkantoor in de arm moet nemen. Bij multinationale bedrijven bestaat weliswaar behoefte aan juristen die naast een grondige kennis van het nationale recht ook een goede kennis hebben van het Europees recht, maar zelfs deze bedrijven kunnen zich niet de luxe permitteren om full-time een dergelijke specialist zelf in huis te hebben. Wanneer zaken in het buitenland worden gedaan, wordt meestal een lokale advocaat ingehuurd om de belangen van de onderneming te behartigen.

Bij de advocatenkantoren is de behoefte aan specifiek Europeesrechtelijk geschoolde juristen beperkt. De kleine advocatenkantoren hebben well in toenemende mate behoefte aan Europeesrechtelijke expertise, maar kunnen het zich, door het geringe aantal Europeesrechtelijke zaken dat zij krijgen, niet veroorloven om een dergelijke specialist in huis te hebben. Ook bij de grotere kantoren is de behoefte aan specialisten op het gebied van het Europees recht beperkt. Veel grotere kantoren hebben weliswaar een sectie Europees recht binnen het kantoor, maar in deze secties werken relatief weinig advocaten. Voor grensoverschrijdende problemen, waarbij specifieke kennis van een ander rechtsstelsel noodzakelijk is, schakelen de kantoren bij voorkeur lokale advocaten in omdat deze beter, sneller en goedkoper in staat zijn een oplossing voor het probleem te geven.

In de overige zakelijke dienstverlening zoals banken en verzekeringsmaatschappijen, valt een toenemende behoefte aan Europeesrechtelijke juristen te constateren. Door de toegenomen internationalisering van de dienstensector ontstaat er meer behoefte aan specifieke kennis van het Europees recht en aan mensen die "over de grens' hebben gekeken. De meeste instellingen in deze sector werven echter academici voor een loopbaan en niet voor specifieke functies. Bij deze werving zouden Europeesrechtelijke juristen wel een voordeel hebben ten opzichte van andere juristen.

Concluderend zou gesteld kunnen worden dat de markt voor specifiek Europeesrechtelijke juristen relatief klein is. De meeste Europeesrechtelijke juristen zullen bij de ministeries of bij de 
Europese instellingen terecht komen. Een geringe markt voor deze juristen bestaat bij de grotere advocatenkantoren die gespecialiseerde secties Europees recht hebben en bij de overige zakelijke dienstverlening. Bij de advocatuur zal echter niet de primaire markt voor deze juristen liggen. Bij de industriële ondernemingen is de behoefte aan deze juristen vrijwel nihil.

\subsubsection{De toekomstige behoefte aan Europeesrechtelijke juristen}

De meeste gesprekspartners geven aan dat de behoefte aan internationaal georiënteerde juristen de komende jaren wel zal toenemen. Dit heeft dan vooral te maken met globalisering en toename van internationale wet- en regelgeving. Bij de Europese Gemeenschap zal het aantal functies voor Europeesrechtelijke juristen toenemen. Bovendien zal in reeds bestaande functies meer aandacht aan het Europees recht besteed gaan worden en zullen juristen steeds meer en in een eerder stadium betrokken worden bij de Europese wet- en regelgeving. Doordat een deel van de functies bij de Europese Gemeenschap in de toekomst waarschijnlijk echter bij de lidstaten zal komen te liggen, zal naar verhouding de toename van het aantal functies bij de Europese Gemeenschap beperkt blijven. Wel wordt gewezen op het toegenomen belang van het Europees parlement na het verdrag van Maastricht, waardoor ook hier eventueel nieuwe functies gecreëerd zullen gaan worden. Verschillende gesprekspartners wezen erop dat met name Oost-Europa de komende jaren een belangrijk werkterrein zal worden.

Bij de rechterlijke macht in Nederland zullen waarschijnlijk geen nieuwe functies op het gebied van het Europees recht gecreëerd worden. Mede door de overheveling van functies van Brussel naar de lidstaten en de toenemende internationale contacten, wordt bij de ministeries meestal wel een toenemende behoefte aan Europeesrechtelijke juristen verwacht. Ook zal het belang van het Europees recht binnen de bestaande functies toenemen. Bij enkele ministeries werd erop gewezen dat vooral een algemene kennis van buitenlandse rechtsstelsels steeds belangrijker zal worden. In plaats van het ministerie van Buitenlandse Zaken zullen de diverse vakministeries steeds vaker eigen Europese specialisten naar Brussel sturen, waardoor bij deze ministeries de behoefte aan Europeesrechtelijke juristen zal groeien.

Verder zal, door de steeds groter wordende internationale samenwerkingsverbanden het aantal Europeesrechtelijke banen in de advocatuur en in beduidend mindere mate het bedrijfsleven, worden uitgebreid. In het bedrijfsleven zal het aantal banen voornamelijk toenemen bij bedrijven die regelmatig met de overheid (en zodoende met Europese wet- en regelgeving) in aanraking komen, bijvoorbeeld energie- of transportbedrijven. Ook wordt gewezen op het toenemende aantal internationale agentschappen (voor bijvoorbeeld energie en lucht) en internationale belangengroepen, waar ook een toekomstige markt voor Europeesrechtelijke juristen zal kunnen liggen. Over de vraag of er in de nabije toekomst meer werkgelegenheid zal ontstaan bij de (grotere) advocatenkantoren, wordt verschillend gedacht. De meesten menen echter dat in de advocatuur een groeiende markt voor Europese juristen gelegen is.

Om de internationaliseringstrend bij te kunnen blijven houden, zullen ook in de overige zakelijke dienstverlening meer banen op het gebied van het Europees recht gecreëerd worden. 
Concluderend kan worden gesteld dat de toename van Europeesrechtelijke functies vooral gesitueerd wordt bij de Europese Gemeenschap en de ministeries en in mindere mate bij de grote advocatenkantoren en bij zakelijke dienstverlenende instellingen zoals banken, verzekeringsmaatschappijen e.d.

\subsubsection{De concurrenten van de ELS}

De ruime arbeidsmarkt impliceert dat de afgestudeerden van ELS zware concurrentie zullen ondervinden van andere rechtenopleidingen.

Indien aan de opleiding een civiel effect verbonden is, zal men concurrentie ondervinden van:

- de postdoctorale opleidingen Europees recht zoals:

College d' Europe in Brugge,

Vrije Universiteit Brussel,

Universiteit van Amsterdam,

Europa Institut Saarbrücken,

European University Institute Florence,

diverse universiteiten in Engeland;

- postacademische cursussen voor werkenden zoals:

Europees instituut voor Bestuurskunde,

Nederlandse School voor Openbaar Bestuur.

Indien aan de opleiding geen civiel effect verbonden zal worden kan concurrentie verwacht worden van:

- Europese of internationale afstudeerrichtingen bij andere rechtenfaculteiten:

Recht in Europa in Nijmegen,

Internationaal recht in Leiden,

Europese studies in Amsterdam,

Letteren en Management in Leiden;

- Hogere Europese Beroepenopleiding (Haagse Hogeschool).

\subsection{De eisen voor Europeesrechtelijke juristen}

\subsubsection{Kennis van het Nederlands recht}

De gesprekspartners zijn vrijwel unaniem van mening dat een grondige nationaalrechtelijke scholing de basis moet vormen van de ELS. Dit betekent primair kennis van het nationale (algemeen) recht. Hierdoor leert men zorgvuldig juridisch te denken. Pas wanneer men dat onder de knie heeft, kan men gaan denken aan een eventuele specialisatie op het gebied van het Europees recht en de rechtsvergelijking. In paragraaf 4.3 komt aan bod welke eisen het afnemende veld ten aanzien van de Europeesrechtelijke en rechtsvergelijkende kennis stelt.

Door grote bedrijven wordt een Europeesrechtelijke en rechtsvergelijkende specialisatie in de meeste gevallen beschouwd als iets extra's: mooi meegenomen als een kandidaat het heeft, 
maar niet echt noodzakelijk. De reden hiervoor houdt verband met het wervings- en selectiebeleid binnen grote bedrijven, waarbij sollicitanten niet zo zeer worden aangenomen voor een bepaalde functie maar veel meer voor een loopbaan binnen het bedrijf. Uiteraard kan een kandidaat met een dergelijke specialisatie zich wel nadrukkelijker onderscheiden van andere sollicitanten.

\subsubsection{Houdingen en vaardigheden}

Buiten de 'normale' eisen die aan academici worden gesteld, zoals creativiteit, passen binnen de organisatie, in een team kunnen werken, e.d., verwacht men van de (Europeesrechtelijk geschoolde) jurist een aantal specifieke houdingen en vaardigheden.

Algemeen geldt voor juristen dat zij:

- een goede algemene ontwikkeling moeten hebben;

- dienen te beschikken over een goed analytisch denkvermogen, evenals het vermogen om grotere verbanden te zien;

- moeten beschikken over juridisch denkvermogen, of zoals een gesprekspartner het uitdrukte 'being able to work with the sources of law and to manipulate these sources in such a way that a legal problem can be solved';

- flexibel moeten zijn, dit wil zeggen in staat moeten zijn om aan meerdere zaken tegelijk te werken (met name genoemd door advocatenkantoren);

- in toenemende mate commerciële affiniteit moeten hebben (met name genoemd door het bedrijfsleven);

Voor Europeesrechtelijke juristen geldt bovendien dat zij:

- gevoel hebben voor bestuurlijke en politieke verhoudingen (met name genoemd door overheidsinstellingen);

- beschikken over vreemde talenkennis;

- 'open minded' zijn voor andere culturen.

Hieronder wordt nader ingegaan op de twee laatstgenoemde eisen die aan Europeesrechtelijke juristen worden gesteld.

\subsubsection{Talenkennis}

Een goede talenkennis wordt door vrijwel iedereen noodzakelijk geacht. Daarbij moet men in de eerste plaats denken aan een goede schriftelijke en mondelinge uitdrukkingsvaardigheid in de eigen moedertaal. Daarnaast aan een gedegen beheersing van tenminste twee vreemde talen. Bij functies voor de EG en in de advocatuur gaat het bij de voor Nederlanders vreemde talen om het Engels en Frans, bij het bedrijfsleven meer om Engels en Duits. Enkele gesprekspartners wijzen op het toenemend belang van Zuid-en Oosteuropese talen.

Zijn de gesprekspartners vrijwel unaniem in hun oordeel over het belang van vreemde talenkennis, verschil van mening bestaat over de vereiste diepgang van deze talenkennis. Dit varieert van 'eindexamenniveau VWO is voldoende, zolang je de buitenlandse vakliteratuur maar kunt begrijpen' tot 'uitstekend in een vreemde taal, zowel mondeling als schriftelijk kunnen 
communiceren'.

\subsubsection{Ervaring in het buitenland}

Buitenlandervaring, variërend van stages tot studie aan een buitenlandse universiteit, wordt door de meeste gesprekspartners op prijs gesteld, maar niet door iedereen als een noodzakelijkheid gezien.

Studie aan een buitenlandse universiteit ziet men doorgaans als middel om de verworven talenkennis in praktijk te kunnen brengen en als middel om 'open minded' te leren omgaan met mensen van een andere cultuur. Sommige gesprekspartners wijzen er op dat dit doel ook bereikt kan worden door de inbreng van buitenlandse studenten in de Maastrichtse opleiding.

Evenals een studieperiode aan een buitenlandse universiteit hebben buitenlandse stages primair als doel om talenkennis toe te passen en een open oog te krijgen voor andere culturen. Daarnaast worden stageplaatsen als potentiële toekomstige banen beschouwd. Will een stage zinvol zijn, zowel voor de stageverlenende instelling als voor de stagiaire, dan dient deze volgens sommige gesprekspartners tenminste een half jaar te bedragen. Anderen vinden stageduren van ten hoogste drie maanden genoeg. Belangrijker dan de duur van de stage is de kwaliteit van de stageplaats, tenminste volgens sommige gesprekspartners. Zij wijzen in dit verband op het probleem dat kwalitatief goede stageplaatsen slechts beperkt voorhanden zijn, terwijl de vraag naar dergelijke stageplaatsen erg groot is. Een vaak naar voren gebrachte suggestie is om een eventuele stage facultatief na het voltooien van de opleiding aan te bieden. De hierdoor vrijgekomen tijd zou dan aan het curriculum besteed kunnen worden.

\subsection{De European Law School}

\subsubsection{Het concept van de European Law School}

Een aantal gesprekspartners wees erop dat het concept van de ELS niet vergeleken kan worden met de Amerikaanse Law School. Ten eerste heeft het federale recht en de "Supreme Court" in de Verenigde Staten een heel andere status dan het Europees recht en het Europese Hof van Justitie. Ten tweede vindt de instroom in de Amerikaanse Law Schools pas plaats nadat men een "college" of een universiteit heeft doorlopen. Ten derde hebben de Verenigde Staten het voordeel dat binnen alle staten dezelfde taal wordt gesproken, waardoor het rechtssysteem als geheel en de rechtsvergelijking in het bijzonder sterk vereenvoudigd wordt.

\subsubsection{Het civiel effect van de opleiding}

De vraag of de opleiding een civiel effect moet hebben wordt door de gesprekspartners zonder meer met 'ja' beantwoord. De meeste gesprekspartners geven aan dat een grondige scholing in het nationale recht de basis moet vormen voor de opleiding. Een volledig Europeesrechtelijk curriculum als zelfstandige discipline wordt daarom door de meeste gesprekspartners 
afgewezen. Hiervoor worden verschillende argumenten aangedragen:

- het Europees recht zou nog onvoldoende tot een zelfstandige 'body of knowledge' zijn uitgegroeid;

- het Europees recht vindt uiteindelijk zijn toepassing in nationale wet-en regelgeving en komt aan de andere kant voort uit deze wet- en regelgeving, met andere woorden er bestaat een interactie tussen deze rechtsstelsels;

- een volledig Europeesrechtelijk curriculum zou een te specialistische basis geven voor een goed functioneren als jurist;

- door het ontbreken van een civiel effect zouden de arbeidsmarktmogelijkheden voor afgestudeerden te sterk worden ingeperkt;

- een aantal belangrijke rechtsbeginselen uit verschillende rechtsgebieden, zoals bijvoorbeeld het strafrecht, het burgerlijk recht en het administratief recht worden niet of nauwelijks bestudeerd in het Europees recht;

- in juridische functies wordt men meer geaccepteerd wanneer men 'meester' is dan wanneer men 'doctorandus' is;

- voor de advocatuur en de rechterlijke macht geldt dat het civiel effect niet slechts als een formele eis moet worden gezien, maar dat de betrokken "Mr." ook daadwerkelijk over de vereiste kennis zal moeten beschikken.

\subsubsection{De verhouding nationaal- Europeesrechtelijk curriculum}

In de regel is men van mening dat minimaal twee tot drie jaar scholing in het nationale recht moet plaatsvinden om op een adequate wijze als jurist te kunnen functioneren. Bij de opbouw van het curriculum zijn in het aanbod van nationaal recht en Europees recht verschillende modellen denkbaar. Het meest eenvoudige model gaat uit van een opbouw waarbij gestart wordt met het nationaalrechtelijk curriculum (twee tot drie jaar full-time) gevolgd door éen of twee jaar full-time Europeesrechtelijk en rechtsvergelijkend curriculum. Het voordeel van dit model is, dat ook buitenlandse studenten relatief gemakkelijk aan het studieprogramma kunnen deelnemen. Het nadeel van een dergelijke curriculumopbouw is dat het nationale recht niet tot het einde van de studie bestudeerd zal worden, waardoor de studenten hun "voeling" voor het nationale recht verliezen. Bovendien zullen het Europees recht en de rechtsvergelijking niet goed als aparte vakken, zonder nationaalrechtelijke onderbouwing, aangeboden kunnen worden.

Enkele gesprekspartners pleitten daarom voor een curriculum waarbij het Europees recht in het nationaal recht geïntegreerd wordt, dat wil zeggen dat er bijna geen aparte blokken Europees recht worden aangeboden maar dat aan elk nationaalrechtelijk blok een Europese en rechtsvergelijkende component wordt toegevoegd. Een nadeel is dat een soortgelijke opleiding reeds in Nijmegen wordt aangeboden, namelijk de studierichting 'Recht in Europa'.

Anderen pleitten voor een piramidaal model, waarbij begonnen wordt met een grote component Nederlands recht die in de loop van de studie zal afnemen met daarnaast een kleine component Europees recht en rechtsvergelijking die in de loop van de studie zal toenemen. Het vaordeel van dit model is dat de studenten gedurende de hele studie het Nederlandse recht blijven 
bestuderen. Het nadeel van een dergelijke opzet is dat het minder eenvoudig zal zijn om buitenlandse studenten tijdens een later stadium van de studie te laten instromen.

\subsubsection{Een pre- of postdoctorale opleiding?}

Deze vraag is niet eenvoudig te beantwoorden, omdat ze nauw samenhangt met de vraag hoe de verhouding in de opleiding dient te zijn tussen het nationaalrechtelijk en Europeesrechtelijk deel van het curriculum. Een (beperkt) aantal gesprekspartners geeft er de voorkeur aan dat de ELS in haar geheel postdoctoraal wordt, waarbij gestreefd zou moeten worden om de opleiding meer status te geven door het aantrekken van buitenlandse docenten. Een nadeel is echter dat er reeds veel postdoctorale opleidingen op het gebied van het Europees recht bestaan en dat Nederlandse studenten die een postdoctorale opleiding Europees recht willen gaan volgen, dit liever in het buitenland zullen willen gaan doen. De concurrentiepositie van de ELS zou juist vergroot worden door de opleiding geheel in het vierjarig eerste fase curriculum te integreren.

\subsubsection{De buitenlandse studenten}

De ELS zal naar verwachting niet aantrekkelijk zijn voor buitenlandse studenten. In veel landen bestaat voor het verkrijgen van het civiel effect de verplichting (bijna) het gehele curriculum in eigen land gevolgd te hebben. De buitenlandse studenten die zouden deel nemen aan de ELS, zouden hierdoor waarschijnlijk geen civiel effect in eigen land kunnen krijgen. Ook zall het voor buitenlandse studenten niet erg aantrekkelijk zijn om de gehele Nederlandsrechtelijke opleiding te volgen. Afgezien van het taalprobleem zouden slechts weinig buitenlandse studenten een civiel effect voor de Nederlandse advocatuur en rechterlijke macht willen verkrijgen.

Het aanbieden van een studieperiode in het buitenland tijdens het curriculum van de ELS zou een ander nadeel voor buitenlandse studenten kunnen zijn. Deze studenten moeten dan opnieuw naar (minstens) één andere universiteit in het buitenland, met als gevolg dat hun studieprogramma uit verschillende, relatief korte studieperiodes aan een universiteit bestaat.

\subsubsection{De selectiviteit van de opleiding}

Gelet op de eisen die aan de opleiding zouden moeten worden gesteld, worden er grote problemen voorzien om de opleiding binnen vier jaar af te ronden. Een oplossing voor dit probleem is het selectief aantrekken van studenten. De opleiding zal moeten recruteren uit de 'betere' studenten. Dit zou al voor de propaedeuse kunnen gebeuren, waarbij de studenten bijvoorbeeld een taaltoets in éen of twee talen moeten afleggen. De studenten die een taal nog onvoldoende beheersen, zouden verplicht een extra-curriculaire bijscholing in deze taal moeten krijgen. $\mathrm{Na}$ de propaedeuse zou geselecteerd kunnen worden op behaalde resultaten. Alleen een selecte groep zal dan kunnen doorstromen naar het tweede jaar ELS. Het vervolg van de opleiding zou zeer zwaar moeten zijn, met slechts weinig afgestudeerden per jaar. Hiermee zou voldaan kunnen worden aan de bestaande, maar geringe vraag naar Europeesrechtelijke juristen. Een enkeling wijst hierbij op het nadeel dat de ELS niet de beste studenten zal kunnen 
recruteren omdat de betere studenten waarschijnlijk een geheel nationaalrechtelijke opleiding gaan volgen en zich pas na hun studie in het Europees recht gaan specialiseren.

\subsubsection{Accent op Europees recht of op rechtsvergelijking?}

De meeste gesprekspartners geven aan dat beide elementen in de opleiding zouden moeten worden opgenomen. Het Europees recht zal in de komende jaren steeds belangrijker worden. Daar echter steeds meer opleidingen het belang van het Europees recht erkennen en in het curriculum opnemen, zou juist de basiskennis van andere (Europese) rechtsstelsels een groot voordeel voor de afgestudeerden van de ELS zijn. Het Europeesrechtelijke deel van het curriculum zou naast het institutioneel Europees recht ook uit materieel Europees recht moeten bestaan.

Over de vraag in welk stadium van de studie met de rechtsvergelijking en het Europees recht moet worden begonnen, bestaat onenigheid. Enkelen vinden dat reeds in een zeer vroeg stadium met de bestudering van andere rechtsstelsels en daarmee met de rechtsvergelijking begonnen moet worden en dat het Europees recht, dat immers uit de verschillende nationale rechtsstelsels is opgebouwd, pas tijdens een later stadium aan bod moet komen.

Anderen vinden dat de rechtsvergelijking een techniek is, die pas geleerd zou kunnen worden als de studenten het nationale recht goed beheersen. De rechtsvergelijking zou dan pas tegen het einde van de studie of zelf als postdoctoraal programma moeten worden aangeboden. Indien toch tijdens een vroeger stadium met de rechtsvergelijking begonnen zou worden, wordt ervoor gepleit om het nationaalrechtelijk deel van het curriculum te beperken tot een bestudering van het Romeins recht en de algemene rechtsbeginselen. Deze rechtsbeginselen zouden vergeleken kunnen worden met de beginselen van andere rechtsstelsels.

Door enkele gesprekspartners werd gewezen op het feit dat de rechtsvergelijking pas mogelijk zal zijn wanneer de studenten niet alleen het nationale recht maar ook de rechtsstelsels waarmee het nationale recht vergeleken moet worden, goed kennen. Dit wordt in een vierjarig curriculum niet haalbaar geacht. De rechtsvergelijking zou dan ook vooral betrekking moeten hebben op het aankweken van een goed gevoel voor verschillen en overeenkomsten tussen rechtsstelsels.

Daarom wordt ervoor gepleit om slechts enkele grote rechtsstelsels zoals het Frans/Latijnse, het Anglo/Amerikaanse en het Germaanse recht te bestuderen in plaats van een algemene rechtsvergelijking van diverse landen. Dit om te voorkomen dat de bestudering van teveel verschillende rechtsstelsels ontaardt in een soort 'legal geography', waarbij de studenten van alles wat weten maar zonder veel diepgang.

Een enkeling gaf aan dat in het laatste jaar een programma opgezet zou kunnen worden waaraan buitenlandse studenten deelnemen. De studenten, van verschillende nationaliteiten, zouden een casus uit de praktijk voorgelegd moeten krijgen, die zij elk vanuit een hun eigen 
nationaalrechtelijke achtergrond moeten oplossen. Vervolgens zou tot een overeenkomst tussen de studenten gekomen moeten worden, waarbij ieders belangen zo optimaal mogelijk behartigd worden. Het voordeel hiervan zou zijn dat de studenten reeds vroeg op een internationaal niveau leren te onderhandelen en al doende vertrouwd raken met andere rechtssystemen. Aan de casus zou bij voorkeur een Europeesrechtelijke component moeten worden toegevoegd.

\subsubsection{De wenselijkheid van een specialisatie naar land}

Een specialisatie naar één land, naast Nederland, wordt in het algemeen ongewenst geacht. Zoals hierboven reeds aangegeven, is een daadwerkelijke beheersing van twee rechtsstelsels binnen een vierjarig curriculum niet haalbaar. Bovendien wordt voor juridische problemen die een specifiek land betreffen in de regel een lokale jurist aangetrokken die waarschijnlijk vlugger en beter een oplossing voor het probleem zal kunnen geven. De studenten zullen, zoals eerder naar voren is gekomen, een goede kennis van het Nederlandse recht en daarnaast een algemene kennis van de rechtsbeginselen van andere rechtsstelsels moeten hebben.

\subsubsection{De wenselijkheid van een specialisatie naar rechtsgebied}

Een (vroege) specialisatie naar rechtsgebied is volgens de meeste gesprekspartners niet wenselijk. De studenten zullen zo breed mogelijk moeten worden opgeleid. De ELS kan reeds gezien worden als een specialisatie binnen het recht en een sub-specialisatie zou daarbij niet noodzakelijk zijn. Het doel van de juridische opleiding is juist de studenten goede juridische vaardigheden te leren. Een verdieping in een bepaald rechtsgebied zal pas na de studie moeten plaatsvinden. Enkele belangrijke rechtsgebieden die echter zeker tijdens de opleiding moeten worden aangeboden zijn: het bestuursrecht, het handels- en ondernemingsrecht, het mededingingsrecht, het verbintenissenrecht en de intellectuele eigendom. Een enkeling wees ook op het toenemende belang in Europese context van het milieu- en agrarisch recht.

\subsubsection{Een buitenlandse stage of studie}

Een buitenlandse stage of studie wordt over het algemeen als nuttig beschouwd. Omdat het programma van de ELS echter reeds behoorlijk zwaar zal worden, zal het beter zijn de buitenlandse stage of studie postdoctoraal aan te bieden. Er zullen goede stageplaatsen gezocht moeten worden, bijvoorbeeld en bij voorkeur bij een internationale instelling of bedrijf, en de student zal tijdens de stage vanuit de universiteit goed begeleid moeten worden. De stage zal minimaal $1 / 2$ jaar moeten duren.

Een studieperiode in het buitenland wordt voornamelijk zinvol geacht om een andere taal en cultuur te leren kennen. Het zou practischer zijn om voor de ELS buitenlandse hoogleraren aan te trekken zodat de studenten leren zowel met een andere taal als met een ander rechtsstelsel te werken. Na de ELS zou aan studenten de mogelijkheid geboden kunnen worden om aan een buitenlandse universiteit te gaan studeren. Wel moet dan rekening gehouden worden met de financiële consequenties voor wat betreft de beurzen die deze studenten dan zouden kunnen 
krijgen.

\subsubsection{De buitenlandse talen}

Een actieve en passieve (juridische) beheersing van tenminste twee buitenlandse talen lop volgorde van belangrijkheid: Engels, Frans, Duits, een Zuid-Europese taal) is uitermate belangrijk voor de ELS studenten. Deze beheersing kan worden verkregen door extra-curriculair taalonderwijs aan te bieden, buitenlandse docenten en studenten aan te trekken, en door het ELS curriculum in het Engels of Frans aan te bieden. 


\section{SAMENVATTING EN CONCLUSIES}

\subsection{De werkgelegenheid voor Europeesrechtelijke juristen}

De huidige arbeidsmarkt voor juristen is zeer ruim, hetgeen weerspiegeld wordt in een relatief hoge werkloosheid onder afgestudeerden. Hoewel in de advocatuur en rechterlijke macht de werkgelegenheid in de nabije toekomst nog zal groeien, blijft de arbeidsmarktsituatie verre van rooskleurig. Dit wordt met name veroorzaakt door het grote aanbod aan afgestudeerden. Vanaf 1995 neemt dit aanbod aan afgestudeerden naar verwachting af.

Op de arbeidsmarkt bestaat een (beperkte) behoefte aan Europeesrechtelijk geschoolde juristen. In de komende jaren zal deze behoefte naar verwachting toenemen. De behoefte aan Europeesrechtelijke juristen kan met name worden gesitueerd bij de ministeries en de Europese Gemeenschap. Daarnaast bestaat een beperkte behoefte aan Europeesrechtelijke juristen bij de grote advocatenkantoren en de overige zakelijke dienstverlening. Bij de industriële ondernemingen is de behoefte aan Europeesrechtelijke juristen vrijwel afwezig.

De concurrentie op de markt voor Europeesrechtelijke juristen zal groot zijn. Bij functies in het hogere segment van de arbeidsmarkt (met name bij de Europese instellingen) zullen afgestudeerden van ELS met name concurrentie ondervinden vanuit de 'gevestigde' postdoctorale opleidingen (Brugge, Florence, Saarbrücken). Bij functies waarvoor geen 'meestertitel' vereist is, zal men concurrentie ondervinden van bijvoorbeeld de internationale afstudeerrichtingen bij andere rechtenfaculteiten of zelfs van vergelijkbare studierichtingen bij andere faculteiten (bijvoorbeeld Europese Studies in Amsterdam). Tenslotte geldt dat door de ruime arbeidsmarkt ook sterke concurrentie ondervonden zal worden van de 'gewone' juristen, die zich in toenemende mate genoodzaakt zien om zich extra te kwalificeren voor de arbeidsmarkt.

\subsection{De eisen voor Europeesrechtelijke juristen}

Een goede scholing in het (eigen) nationale recht is een absolute voorwaarde. Daarnaast dienen deze juristen over voldoende kennis van het institutioneel en materieel Europees recht te beschikken, alsmede een goed gevoel te hebben voor overeenkomsten en verschillen tussen de belangrijkste rechtsstelsels. Voorts dient men een goede beheersing te hebben van minstens twee moderne vreemde talen, liefst Engels en Frans, en open te staan voor andere culturen. Verder dienen zij, evenals andere juristen, te beschikken over een goede algemene ontwikkeling, een goed analytisch en juridisch denkvermogen en flexibiliteit. Praktijkervaring (bij voorkeur via een stage bij een internationale instelling of een gerenommeerde nationale organisatie) strekt tot aanbeveling.

\subsection{De European Law School}

Op de arbeidsmarkt bestaat geen behoefte aan een opleiding met een uitsluitend 
Europeesrechtelijk curriculum. In de opleiding moet ook een grondige scholing in het nationale recht plaatsvinden, zowel vanuit vakdidactische overwegingen als vanwege het civiel effect dat hiermee verbonden is. De meningen zijn verdeeld over de vraag of de ELS in de eerste fase opleiding kan worden ingepast of als postdoctorale opleiding moet worden aangeboden.

De opleiding zal een sterk selectief karakter moeten hebben, gericht op het recruteren van de 'betere' studenten. De totale instroom in de opleiding zal bescheiden moeten zijn, gelet op de beperkte behoefte op de arbeidsmarkt. Omdat het voor buitenlandse studenten moeilijk zal zijn om aan de opleiding een civiel effect in eigen land te ontlenen, zal de instroom in een eerste fase opleiding vanuit het buitenland zeer beperkt zijn.

In de opbouw van het opleidingsprogramma zijn verschillende modellen denkbaar (zie paragrafen 4.3.3 en 4.3.7). Deze modellen verschillen onder meer in de mate waarin het nationaal- en het Europeesrechtelijk curriculum geïntegreerd worden aangeboden, de volgorde waarin de verschillende onderdelen worden aangeboden en de accenten die worden gelegd. De keuze voor een van deze modellen is mede afhankelijk van organisatorische en vakdidactische overwegingen.

Het is niet gewenst dat in de opleiding een specialisatie plaatsvindt naar land of rechtsgebied. In de opleiding dient zowel het Europees recht als de rechtsvergelijking een plaats te krijgen. Daarnaast is het van belang dat de opleiding zich niet uitsluitend op 'Brussel' richt. 


\section{AANBEVELINGEN}

1. Er is een zekere behoefte aan Europeesrechtelijk geschoolde juristen. Hoewel er duidelijke concurrentie is vanuit andere opleidingen zou een European Law School, mits voldaan is aan bepaalde randvoorwaarden (civiel effect, selectief), met redelijk succes op de arbeidsmarkt kunnen opereren. De voorkeur zou daarbij uitgaan naar een eerste fase opleiding, omdat een postdoctorale opleiding teveel concurrentie zal ondervinden van de 'gevestigde' opleidingen, zowel in de strijd om de betere studenten, als in de strijd om de betere banen.

2. Elke rechtenfaculteit 'doet' wel iets aan Europa of zal dat binnen afzienbare tijd gaan doen. Wil Maastricht zich onderscheiden, dan moet de opleiding een sterk selectief karakter hebben en een sterk internationale uitstraling. Dit beeld moet ook benadrukt worden in de voorlichting aan aankomende studenten en in de contacten met het werkveld.

3. Het selectieve karakter houdt per definitie in dat de instroom in de opleiding beperkt zal zijn. Niettemin kan de aanwezigheid van een dergelijke afstudeerrichting de instroom in de gehele faculteit verhogen. Immers, de aanwezigheid van een zware opleiding met een hoge status kan de aantrekkingskracht van de faculteit als geheel vergroten. De public-relations waarde van de ELS moet daarom zoveel mogelijk uitgebuit worden. De rechtenfaculteit kan zich, door het aanbieden van een zware Europeesrechtelijke opleiding, profileren als de 'internationaal' georiënteerde faculteit.

4. De opleiding ELS moet een civiel effect hebben. Dit betekent dat in ieder geval aan de wettelijke minimum vereisten op dit punt moet worden voldaan. Gelet op de eisen vanuit de markt, zal het nationaalrechtelijk deel van de opleiding waarschijnlijk mér dan het minimum moeten omvatten om serieus genomen te worden.

5. Vanwege het ontbreken van een civiel effect van de opleiding in het buitenland, zal de belangstelling van buitenlandse studenten waarschijnlijk gering zijn. Het is dan ook niet verstandig om de werving voor en opbouw van de opleiding af te stemmen op mogelijke buitenlandse studenten.

6. De propaedeuse van de ELS kan worden opgebouwd uit de huidige propaedeuse Nederlands recht plus een aanvullend Europeesrechtelijk deel. Aansluiting bij de bestaande propaedeuse heeft drie voordelen. Ten eerste kan in de propaedeuse een zware selectie plaatsvinden voor studenten die willen doorstromen naar het tweede jaar van het ELS-programma. Een dergelijke selectie is voorafgaand aan de propaedeuse nauwelijks mogelijk. In de tweede plaats kurnen de studenten die 'afvallen' of zich bedenken doorstromen naar de gewone juridische opleiding. Op de derde plaats kan men hierdoor een besparing realiseren op de opleidingskosten. Omdat ook in het ELS programma het beste begonnen kan worden met het Nederlands recht, vallen beide curricula immers voor een belangrijk deel samen. 
7. De selectie in de propaedeuse moet betrekking hebben op zowel de behaalde resultaten als de aanwezige talenkennis. Met behulp van een entree toets in het begin van het eerste studiejaar kan worden vastgesteld in hoeverre de kennis van het Engels en het Frans tekortschiet. Deze talenkennis moet zonodig via gerichte taalcursussen buiten het reguliere programma om tot een bepaald minimum worden bijgespijkerd.

8. Zowel tijdens de propaedeuse als gedurende het eigenlijke ELS programma moet de studenten de nodige faciliteiten worden geboden om, eveneens buiten het reguliere programma om, de aanwezige talenkennis verder te ontwikkelen. De ontwikkeling van de talenkennis moet verder zoveel mogelijk als een nevenproduct van het curriculum worden georganiseerd, bijvoorbeeld door het werken met buitenlandse (gast)docenten of via een (postdoctorale) stage of studie in het buitenland.

9. Het ELS programma zelf zou als een driejarige vervolgopieiding na de propaedeuse Nederlands recht moeten worden aangeboden. In deze drie jaar moet de student in versneld tempo een basiscurriculum nationaal recht dooriopen. Door het basiscurriculum in versneld tempo te laten doorlopen, worden twee doelen bereikt: de opleiding wordt zwaarder (dus selectiever) en men doet voldoende kennis op van het nationale recht om serieus te kunnen opereren op de arbeidsmarkt. In totaal zou één tot anderhalf jaar besteed kunnen worden aan Europees recht en rechtsvergelijking. De rechtsvergelijking zou voornamelijk betrekking moeten hebben op de vergelijking van de belangrijkste rechtsstelsels (Anglo-Amerikaans, Frans-Latijns en het Germaans).

10. Om het eigen karakter van de opleiding te benadrukken, zou in het eerste jaar reeds met Europees recht begonnen moeten worden. Langzamerhand zou, volgens het piramidaal model, het aandeel van het Europeesrechtelijk curriculum moeten toenemen. Het is van belang om ook in het laatste jaar van de opleiding nog enige aandacht aan het Nederlands recht te besteden om 'voeling' met het nationale recht te houden. De faculteit zou zich moeten bezinnen op de vraag in hoeverre het nationaal-rechtelijk en het Europeesrechtelijk curriculum geïntegreerd kunnen worden aangeboden. De wenselijkheid van een dergelijke integratie is mede afhankelijk van organisatorische en vakdidactische overwegingen.

11. In het vierde jaar zouden de studenten een aantal geselecteerde Europese casussen kunnen behandelen. Een goede opzet zou zijn om de studenten, samen met buitenlandse studenten, een Europese richtlijn te laten ontwerpen. Elke student moet dan de inpassing in het eigen rechtsstelsel verzorgen. De casus moet betrekking hebben op een probleem dat binnen afzienbare tijd op EG-niveau behandeld zal gaan worden. De voorbereiding kan in het eigen land plaatsvinden, terwijl voor de onderhandelingen de buitenlandse studenten voor bijvoorbeeld een aantal weken naar Maastricht worden uitgenodigd. Een dergelijke werkwijze sluit goed aan bij de PGO-filosofie. Het is verstandig om de EG bij de opzet hiervan nauw te betrekken. Dit kan door een vertegenwoordiger van de EG de behandeling van de casus te laten bijwonen en te laten evalueren. Het verdient wellicht aanbeveling om in een dergelijke opzet een competitief element in te brengen. De studenten die de casus het best behandelen moeten bijvoorbeeld een 
stageplaats in Brussel aangeboden krijgen.

12. Hoewel stages belangrijk zijn, nemen ze veel tijd in beslag. Een goede stage duurt éen half jaar, terwijl het curriculum toch al overladen is. Belangrijk is dat de faculteit een netwerk creëert van interessante stageverlenende instellingen. Dit netwerk zal de student ter beschikking staan wanneer hij of zij op zoek gaat naar een stageplaats. Deze zou bij voorkeur na afloop van de opleiding moeten plaatsvinden. Voor stageplaatsen bij de EG geldt overigens reeds dat deze uitsluitend open staan voor afgestudeerden. Dit zal wellicht vaker voor interessante stageplaatsen gelden. Van belang is dat de student uiteindelijk zelf de stageplaats moet verwerven. De rol van de faculteit blijft beperkt tot het leggen van contacten.

13. Het is van groot belang dat bij de uitvoering van het Europeesrechtelijk curriculum buitenlandse gastdocenten en -onderzoekers worden aangetrokken. Dit bevordert de internationale oriëntatie van de studenten en heeft een positieve uitwerking op het imago van de opleiding.

14. Het verdient aanbeveling om belangrijke sleutelfiguren uit het (internationale) werkveld nauw bij de opleiding te betrekken, bijvoorbeeld door hen zitting te laten nemen in een programma- of examencommissie. Op deze wijze kan een netwerk gecreëerd worden waardoor enerzijds de opleiding signalen kan ontvangen welke eisen door het (toekomstige) werkveld gesteld gaan worden, en anderzijds de opleiding meer bekendheid en erkenning op de arbeidsmarkt verkrijgt. 


\section{LITERATUUR}

Berg Saparoea, F.W. van (1988), Jurist en arbeidsmarkt. Onderzoek naar arbeidsmarktontwikkeling voor juristen en de gevolgen daarvan voor de juridische opleiding, Stichting Centrum voor Onderwijsonderzoek, Amsterdam.

Commissie Internationalisering (1992), De European Law School, Faculteit der Rechtsgeleerdheid Rijksuniversiteit Limburg.

Ramaekers, G.W.M., J.A.M. Heijke (1991), Arbeidsmarktscanner Rijksuniversiteit Limburg: Afgestudeerden 1986-1989, ROA-R1991/6, Maastricht.

Researchcentrum voor Onderwijs en Arbeidsmarkt (1992-11), Statistische bijlage: De arbeidsmarkt naar opleiding en beroep tot 1994, ROA-R-1992/1B, Maastricht.

Hassel, W.G. van, etal (1992), Gevraagd: "Jurist voor morgen". De juridische opleiding in de toekomst, Faculteit der Rechtsgeleerdheid Katholieke Universiteit Nijmegen.

Velsen, J. van (1993), WO Verdeelraming 1992, Ministerie van Onderwijs en Wetenschappen, Den Haag.

Verhulst-van der Lans, M.C., D.R. Lagrouw (1992), Meesters op de markt. Een onderzoek onder werkgevers naar de arbeidsmarktpositie van pas afgestudeerde juristen, Faculteit der Rechts. geleerdheid, Rotterdam. 


\section{BIJLAGE I. LIJST VAN GEINTERVIEWDE PERSONEN}

- Ministerie van Buitenlandse Zaken

C.J. Kole, afdeling Werving, Selectie en Opleiding

- Ministerie van Justitie

A.M.A. Ehren, coördinator Management / Development

J.H. van Kreveld, hoofd Stafafdeling Algemeen Wetgevingsbeleid

- Ministerie van Binnenlandse Zaken

G. Kreffer, Directoraat Generaal Management en Personeelsbeleid

C.R. Niessen, stafafdeling Constitutionele Zaken en Wetgeving

- Ministerie van Economische Zaken

S.A. Kuipers, Directie Europa

- Ministerie van Welziin, Volksgezondheid en Cultuur

E. Steyger, afdeling Wetgeving en Juridische Zaken

J.A. Janssen, afdeling Wetgeving en Juridische Zaken

- Nederlandse Vereniging voor Rechtspraak

P.H.A.J. Cremers, Conrector Stichting Studiecentrum Rechtspleging

- Bureau Internationale Ambtenaren

E. Sippel, produktmanager Internationale Ambtenaren

- Europees Hof van Justitie
A. Alvarez
D. Edward, rechter

A.G. W. van Gerven, advocaat generaal

- Commissie van de Europese Gemeenschappen

$X$. Lewis, Juridische Dienst

P.J. Kuyper, Juridische Dienst

\section{- Barentz \& Krans}

G. van der Wal, advocaat, sectie Europees recht

W.B.J. van Overbeek, stagiair, sectie Europees recht

- Buruma Maris Scheer van Solkema

I.G.F. Cath, advocaat, sectie Europees recht 
- De Brauw Blackstone Westbroek

E.H. Pijnacker-Hordijk, advocaat, sectie Europees recht

- Loeff Claevs Verbeke

T.R. Ottervanger, advocaat, sectie Europees recht

- Trenité van Doorne

D.C. Buijs, recruitment partner, advocaat

- Veldhuvzen en Schep advocaten, international consultants law group M.L. Veldhuyzen, advocaat

- Time Warner Europe

M. Kohnstamm, Manager EC Public Affairs

W. van Weert, advocaat

- Conseil des Barreaux De La Communauté Europeenne (CCBE)

J. Fish, Commission 'Legal education and the problems of the young lawyer'

- Nationale Nederlanden

J.J. Douwes, hoofd Stafbureau Management / Development

- DSM

J.J. van Ruyven, Corporate Recruitment

E.P. Heiden, afdeling Juridische Zaken

- Unilever NV

H.J.M.N. Honée, bedrijfsjurist Unilever en voorzitter Commissie Vennootschapsrecht van het Genootschap van Bedrijfsjuristen

- Coopers en Lybrand

A.A.G. Fluitman, voorzitter van het bestuur van Coopers \& Lybrand belastingadviseurs

- Union of Industrial and Employers' Confederations of Europe (UNICE)

H. Kroeger, Director of Company Affairs Department

- M. van Empel

Hoogleraar Europees recht, Universiteit van Amsterdam

Advocaat bij Stibbe \& Simont Amsterdam

- Meertens

Advocaat 


\section{BIJLAGE 2. CONCURRERENDE OPLEIDINGEN}

Universiteit van Amsterdam: Internationaal-Juridische studierichting.

Bij deze studierichting krijgen de afgestudeerden de 'drs. '-titel. Het programma bestaat onder meer uit de volgende onderdelen: internationaal recht, volkenrecht, recht der internationale organisaties, recht der Europese Gemeenschappen, internationale betrekkingen, internationale economische betrekkingen, internationaal privaatrecht, staats- en bestuursrecht, privaatrecht/vermogensrecht, rechtsvergelijking, rechtsgeschiedenis, rechtssociologie, economie, internationaal onderzoeksproject, keuze-onderdelen en een internationale specialisatie. Het doel van de opleiding is juristen op te leiden voor functies, waar kennis van het internationale recht nuttig of onmisbaar is, bijvoorbeeld bij de overheid, het bedrijfsleven of internationale organisaties.

Rijksuniversiteit Leiden: Internationaal-Juridische studierichting.

Bij deze studierichting krijgen de afgestudeerden de 'drs.'-titel. Het programma bestaat onder meer uit de volgende onderdelen: volkenrecht, recht der internationale organisaties, recht der Europese Gemeenschappen, de leer der internationale betrekkingen, privaatrecht en internationale economische betrekkingen. De beroepsmogelijkheden voor de afgestudeerden liggen vooral in de publiekrechtelijke sfeer, dat wil zeggen bij de nationale of internationale overheid en bij maatschappelijke organisaties, die zich bezig houden met internationale politiek. Slechts enkele afgestudeerden komen bij de universiteit, de journalistiek of het bedrijfsleven terecht.

Universiteit Utrecht: Internationaal-Juridische studierichting.

Deze studie leidt tot de titel 'doctorandus in de rechtsgeleerdheid' en geeft geen toegang tot de advocatuur, rechterlijke macht of het openbaar ministerie. Het programma bestaat ondermeer uit de volgende onderdelen: juridische aspecten van internationale betrekkingen, economische en politieke aspecten alsmede de historische ontwikkelingen van het internationaal recht. De beroepsmogelijkheden liggen vooral bij inter- en supranationale organisaties, het ministerie van Buitenlandse Zaken en multinationals. De studenten moeten een goede actieve en passieve beheersing van tenminste twee moderne talen hebben. De studie wordt door slechts $2 \%$ van de Utrechtse rechtenstudenten gekozen.

Rijksuniversiteit Groningen: het vrije doctoraal, waarbinnen kan worden gekozen voor 'Internationaal recht en Internationale betrekkingen'. Bij deze studierichting krijgen de afgestudeerden de 'drs.'-titel. Het programma bestaat onder meer uit de onderdelen Europees recht, Volkenrecht, Polemologie, Sociologie der Internationale Betrekkingen, Eigentijdse Geschiedenis, Internationale Economie en een taal. Het is een praktijkgerichte opleiding voor studenten die een werkkring ambiëren in internationaal werkzame organisaties.

Katholieke Universiteit Nijmegen: Recht in Europa.

De afgestudeerden krijgen de titel 'meester in de rechten'. Na een gemeenschappelijke propaedeuse, kunnen de studenten uit de afstudeerrichtingen Nederlands recht (algemene 
variant), Nederlands recht (Recht in Europal of de notariële richting kiezen. In het eerste doctoraaljaar krijgen de studenten drie hoofdvakken van het Nederlands recht: staatsrecht, bestuursrecht en strafrecht. Binnen deze variant worden ze ook toegepast op andere EG-landen. Verder krijgt men geschiedenis van de Europese rechtsstelsels, volkenrecht en inleiding Europees recht. In het tweede doctoraaljaar worden de vakken burgerlijk recht, burgerlijk procesrecht, ondernemingsrecht, recht der Europese Gemeenschappen, rechtsfilosofie of rechtssociologie lafgestemd op de Europese ontwikkelingen, met name op het terrein van de rechten van de mens) aangeboden. Studenten kiezen in het afstudeerjaar vakken met een Europeesrechtelijk of internationaalrechtelijk accent. Bovendien brengen ze in het kader van het Erasmusprogramma van de EG een half jaar of langer door aan éen van de juridische faculteiten van buitenlandse universiteiten waarmee Nijmegen contacten onderhoudt. Talenkennis is voor een jurist binnen Recht in Europa van groot belang. Frans, Duits en Engels moeten de studenten op VWO-eindexamenniveau beheersen. Een talencursus kan in de propaedeuse extra-curriculair worden gevolgd. De juridische faculteit in Nijmegen mikt met de juridische opleidingen voornamelijk op de sectoren advocatuur, bedrijfsleven, rechterlijke macht en op de overheid. 


\begin{tabular}{|c|c|c|c|c|c|}
\hline & $\begin{array}{l}\text { Community } \\
\text { law }\end{array}$ & $\begin{array}{l}\text { European } \\
\text { economics }\end{array}$ & $\begin{array}{l}\text { European } \\
\text { political science }\end{array}$ & Multidisciplinary & Others \\
\hline BELGIUM & $\begin{array}{l}\text { Bruxelles-ULB } \\
\text { Brussel-VUB } \\
\text { Gent } \\
\text { Liège } \\
\text { Louvain } \\
\text { Brugge-College of } \\
\text { Europe }\end{array}$ & $\begin{array}{l}\text { Bruxelles-ULB } \\
\text { Brugge-College of } \\
\text { Europe }\end{array}$ & Bruxelles-ULB & $\begin{array}{l}\text { Bruxelles-ULB } \\
\text { Louvain }\end{array}$ & $\begin{array}{l}\text { Brugge-Collego of } \\
\text { Europe }\end{array}$ \\
\hline DENMARK & $\begin{array}{l}\text { Kobenhavns Univ. } \\
\text { Handelshajskolen } \\
\text { Kobenhavn }\end{array}$ & & Aarthus & $\begin{array}{l}\text { Aalborg } \\
\text { Aarhus }\end{array}$ & \\
\hline $\begin{array}{l}\text { GERMANY } \\
\text { (former FR) }\end{array}$ & $\begin{array}{l}\text { Augsburg } \\
\text { Bayreuth } \\
\text { Bonn } \\
\text { Freiburg } \\
\text { Göttingen } \\
\text { Hamburg } \\
\text { Hannover } \\
\text { Heidelberg } \\
\text { Köln } \\
\text { Konstanz } \\
\text { München } \\
\text { Osnabrück } \\
\text { Passau } \\
\text { Regensburg } \\
\text { Saarbrücken } \\
\text { Tübingen } \\
\text { Würzburg } \\
\end{array}$ & $\begin{array}{l}\text { Berlin } \\
\text { Bayreuth } \\
\text { Hamburg } \\
\text { Hannover } \\
\text { Heidelberg } \\
\text { Köln } \\
\text { Konstanz } \\
\text { Siegen }\end{array}$ & $\begin{array}{l}\text { Darmstadt } \\
\text { Köln } \\
\text { Mainz } \\
\text { Trier }\end{array}$ & $\begin{array}{l}\text { Berlin } \\
\text { Bielefeld } \\
\text { Bremen } \\
\text { Dulsburg } \\
\text { Essen } \\
\text { Erlangen-Nürnberg } \\
\text { Giessen } \\
\text { Mannheim } \\
\text { (Europa Institut) } \\
\text { Marburg } \\
\text { München } \\
\text { Münster } \\
\text { Nürnberg } \\
\text { Saarbrücken } \\
\text { (Europa Institut) } \\
\text { Tübingen }\end{array}$ & $\begin{array}{l}\text { Boohum } \\
\text { Frankfurt } \\
\text { Kial } \\
\text { Maine }\end{array}$ \\
\hline SPAIN & $\begin{array}{l}\text { Barcelona } \\
\text { Madrid } \\
\text { San Sebastian } \\
\text { Valladolid }\end{array}$ & $\begin{array}{l}\text { Barcelona } \\
\text { Bibao } \\
\text { Madrid } \\
\text { Santander } \\
\text { Valladolid } \\
\end{array}$ & Bilbeo & $\begin{array}{l}\text { Bilbao } \\
\text { Madrid } \\
\text { Barcelona } \\
\text { Salamanca } \\
\text { Zaragoza } \\
\end{array}$ & $\begin{array}{l}\text { Granada } \\
\text { Madrid }\end{array}$ \\
\hline FRANCE & $\begin{array}{l}\text { Paris I-CUECE } \\
\text { Paris-UERI } \\
\text { Paris II } \\
\text { Paris V } \\
\text { Paris XI } \\
\text { Strasbourg III } \\
\text { Rennes } \\
\text { Nancy II }\end{array}$ & $\begin{array}{l}\text { Nancy II } \\
\text { Paris I-CUECE } \\
\text { Paris II } \\
\text { Paris XIII } \\
\text { Strasbourg I }\end{array}$ & Strasbourg III & $\begin{array}{l}\text { Aix-Marseille III } \\
\text { Grenoble II } \\
\text { Nancy II } \\
\text { Nice-IEHEI } \\
\text { Strasbourg III } \\
\text { (IIHEE) } \\
\text { Toulouse I } \\
\text { IEP } \\
\text { Lille II } \\
\text { Lyon III }\end{array}$ & $\begin{array}{l}\text { Nanoy II } \\
\text { Strasbourg III }\end{array}$ \\
\hline IRELAND & $\begin{array}{l}\text { University College } \\
\text { Dublin }\end{array}$ & & & $\begin{array}{l}\text { Limerick } \\
\text { University College } \\
\text { Dublin } \\
\text { Cork } \\
\end{array}$ & \\
\hline ITALY & $\begin{array}{l}\text { Parma } \\
\text { Firenze (IUE) } \\
\text { Torino }\end{array}$ & $\begin{array}{l}\text { Millano } \\
\text { Torino }\end{array}$ & & $\begin{array}{l}\text { Roma (Insitute of } \\
\text { European studies) } \\
\text { Firenze (European } \\
\text { University Institute } \\
\text { Firenze (School of } \\
\text { higher international } \\
\text { studies) } \\
\text { Calabria } \\
\text { Univ. de Roma }\end{array}$ & $\begin{array}{l}\text { Bologna Center } \\
\text { Johns Hopkins } \\
\text { University }\end{array}$ \\
\hline THE NETHERLANDS & $\begin{array}{l}\text { Leiden } \\
\text { Utrecht }\end{array}$ & & & $\begin{array}{l}\text { Amsterdam } \\
\text { Rotterdam } \\
\text { Tilburg } \\
\end{array}$ & \\
\hline PORTUGAL & Coimbra & $\begin{array}{l}\text { Lisboa } \\
\text { Coimbra } \\
\end{array}$ & & & \\
\hline UNITED KINGDOM & $\begin{array}{l}\text { Essex } \\
\text { Edinburgh } \\
\text { Exeter } \\
\text { Glasgow } \\
\text { Leeds University } \\
\text { Leeds Polytechnic } \\
\text { Leicester } \\
\text { Manchester } \\
\text { Wairwick } \\
\text { Southampton } \\
\text { London School of } \\
\text { Economics } \\
\text { Hull } \\
\text { City of London- } \\
\text { Polytechnic }\end{array}$ & $\begin{array}{l}\text { Exeter } \\
\text { London School of } \\
\text { Economics } \\
\text { Cardiff }\end{array}$ & $\begin{array}{l}\text { Birmingham } \\
\text { Birmingham- } \\
\text { Polytechnic } \\
\text { Edinbugh } \\
\text { Essex } \\
\text { Lancaster } \\
\text { Leeds } \\
\text { London School } \\
\text { of Economics } \\
\text { Warwick } \\
\text { Coventry- } \\
\text { Polytechnic } \\
\text { City of London }\end{array}$ & $\begin{array}{l}\text { Bath } \\
\text { Durham } \\
\text { East Anglia } \\
\text { Glasgow } \\
\text { Keele } \\
\text { Kent } \\
\text { Leeds Polvtechnic } \\
\text { London School of } \\
\text { Econornics } \\
\text { University of } \\
\text { London- } \\
\text { King's College } \\
\text { Manchester } \\
\text { Reading } \\
\text { Southampton } \\
\text { Sussex } \\
\text { Warwick } \\
\text { Hull }\end{array}$ & $\begin{array}{l}\text { Aberdeen } \\
\text { Bath } \\
\text { Manchester } \\
\text { Sussex } \\
\text { Coventry- } \\
\text { Polytechnic }\end{array}$ \\
\hline ISRAEL & & & Jerusalem & & \\
\hline SWITZERLAND & & & Genève & & \\
\hline TURKEY & & & istanbul & & \\
\hline
\end{tabular}


KUB RL UU EUR KUN RUL RUG VU UVA OU

European company and business law

- Europees recht

- Europees belastingrecht

- Europees consumentenrecht

Europees economisch recht

- Europees institutioneel recht

- Europees jaarrekeningenrecht

- Europese integratie

- Europees milieurecht

- Europese politiek

- Europese strafrechtelijke samenwerking en strafrechterlijk beleid

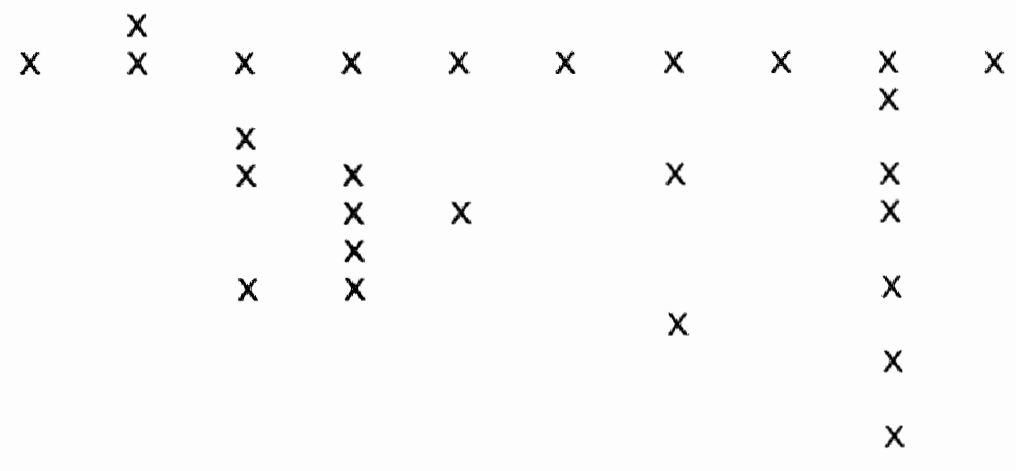

